\title{
PEMANFAATAN TEKNOLOGI HIDROPONIK SAYURAN ORGANIK BERBANTUAN PANEL SURYA (HYDROPONIC SOLAR PANELS)
}

\author{
Iryana Muhammad ${ }^{1 *}$, Nuraini Fatmi ${ }^{2}$, alchalil ${ }^{3}$ \\ ${ }^{1}$ Program Studi Pendidikan Matematika, Universitas Malikussaleh \\ ${ }^{2}$ Program Studi Pendidikan Fisika, Universitas Malikussaleh \\ ${ }^{3}$ Program Studi Pendidikan Vokasi Teknik Mesin, Universitas Malikussaleh \\ *e-mail: iryana.muhammad@unimal.ac.id
}

\begin{abstract}
Abstrak: Pengabdian ini di lakukan di Desa Meuria Paloh Kecamatan Muara Satu Kota Lhokseumawe. Hasil observasi awal melalui wawancara team pengabdian dengan mitra di desa Meuria Paloh, permasalahan yang umum terjadi di tanaman hidroponik adalah pemakaian listrik selama 24 jam dikarenakan aliran air nutrisi mengandalkan pompa listrik, jika listrik mati maka aliran nutrisi pun terhenti, adapun permasalahan prioritas di alami mitra adalah selain pemakaian listrik 24 jam juga seringnya pemadaman listrik di desa serta berpengaruh pada debit air, jika tidak ideal 1-2 liter/menit maka tanaman akan mati. Tanaman hidroponik berbantuan panel surya selain menghemat lahan juga menghemat energi cara ini sangat menguntungkan. Tujuannya adalah untuk menumbuhkan perekonomian masyarakat serta menghemat energi listrik. Berdasarkan hasil kegiatan yang dilakukan di lokasi Angrowisata Hidroponik dan angket yang disebarkan didapatkan respon dari masyarakat yang luar biasa. Penghematan biaya yang dikeluarkan secara signifikan memberikan pengaruh terhadap profit yang dihasilkan.
\end{abstract}

\section{Kata Kunci: Teknologi, Hidroponik, Panel Surya}

\section{THE USE HYDROPONIC TECHNOLOGY ASSISTED ORGANIC VEGETABLES SOLAR PANELS (HYDROPONIC SOLAR PANELS)}

\begin{abstract}
This service was carried out in Meuria Paloh Village, Muara Satu District, Lhokseumawe City. The results of preliminary observations through the community service team interview with partners in the village of Meuria Paloh, a common problem in hydroponic plants is the use of electricity for 24 hours because the flow of nutrient water relies on an electric pump, if the electricity goes out, the flow of nutrients stops, as for priority problems experienced by partners In addition to 24-hour electricity usage, there are frequent power cuts in the village and it affects the water flow, if it's not ideal, 1-2 liters / minute, the plants will die. In addition to saving land, hydroponic plants assisted by solar panels also save energy, this method is very profitable. The goal is to grow the community's economy and save electrical energy. Based on the results of the activities carried out at the location of the Hydroponic Ecotourism and the questionnaires that were distributed, there was an extraordinary response from the community. The cost savings incurred significantly have an effect on the resulting profit.
\end{abstract}

Keywords: Hydroponic, Technology, Solar Panels 


\section{PENDAHULUAN}

Pengabdian ini dilakukan bersama kelompok masyarakat dan team dosen, dengan tujuan untuk mendongkrak semangat perekonomian melalui pemanfaatan lahan di perkotaan, namun pemanfaatan ini di fokuskan ke tanaman hidroponik berbantuan panel surya. Memperkenalkan hidroponik berbantuan panel surya ke kelompok masyarakat harus dengan cara yang mudah dipahami dan terlihat menarik. Hidroponik merupakan teknik budidaya tanaman tanpa menggunakan media tanah, melainkan menggunakan rockwool, aram sekam, hydrogel, kerikil, cocopeat, pasir dan air sebagai media tanamnya. Keuntungan hidroponik adalah: (a) tidak memerlukan lahan yang luas (b) mudah dalam perawatan (c) memiliki nilai jual yang tinggi. Sedangkan kelemahan hidroponik adalah: (a) memerlukan biaya yang mahal (b) membutuhkan keterampilan yang khusus. Mengacu pada perkembangan ilmu dan teknologi kelistrikan maka kebutuhan modifikasi sistem hidroponik perlu dilakukan agar sistem hidroponik semakin baik. Karena sistem hidroponik tidak bisa lepas dari air maka perlu dibuat sistem pengatur sirkulasi air otomatis menggunakan tenaga surya. Tenaga surya bisa dijadikan solusi sebagai pemanfaatan energi terbarukan (Cristian, 2010). Bagi pemula yang ingin bertanam dengan cara hidroponik prinsipnya sangat mendasar hanya memanfaatkan kapilaritas air. Keunggulan lainnya adalah tidak memerlukan perawatan khusus, mudah dalam merakit, portabel (dapat dipindahkan), dan cocok di lahan terbatas (Diah, 2015).

Menjadi wirausaha hal yang sangat menarik dikarenakan menawarkan kebebasan keuangan. Selain itu, bisa bebas mendesain sendiri jenis bisnis yang ingin dijalankan, mulai dari rencana atau jasa, hingga menentukan target konsumen. Keberadaan dosen sebagai pemandu dan pembimbing dalam pemanfatan tanaman hidroponik akan memberikan manfaat sebagai fasilitator dari sarana dan ilmu yang dibutuhkan. Selain itu team pengabdian juga dapat bertindak sebagai mediator jika kelompok masyarakat yang bersangkutan mendapatkan suatu permasalahan yang sulit ditangani atau didiskusikan penyelesaiannya. Peran mitra juga sangat penting dalam hal ini, mitra berperan memberikan informasi dan menjelaskan konsep pemasaran yang tepat dan efektif untuk penjualan produk hidroponik yang optimal dengan kondisi titik tanam yang terbatas serta di kondisi pandemic Covid-19.

Berdasarkan hasil observasi awal team pengabdian di lapangan, menemukan bahwa tanaman hidroponik merupakan tanaman yang sangat efektif di kembangan dikalangan milenial ini, berdasarkan hasil wawancara team pengabdian dengan mitra di desa Desa Meuria Paloh Kota Lhokseumawe, menemukan bahwa tanaman hidroponik merupakan tanaman yang sangat cocok digunakan untuk orang yang bertempat tinggal diperkotaan karena disana tidak tersedia lahan, permasalahan yang umum terjadi di tanaman hidroponik adalah pemakaian listrik selama 24 jam dikarenakan aliran air nutrisi mengandalkan pompa listrik, jika listrik mati maka aliran nutrisi pun terhenti, beranjak dari permasalahan ini maka peneliti ingin menghadirkan solusi yaitu menggunakan hidroponik berbantuan panel surya. Tanaman hidroponik berbantuan panel surya selain menghemat lahan juga menghemat energi cara ini sangat menguntungkan. Dengan demikian hasil observasi ini sangat bermanfaat dalam membangun perekonomian di kalangan masyarakat.

Banyak petani hidroponik komersial dan hobbyist menggunakan sistem NFT untuk menanam sayuran dan tanaman. Sistem NFT dapat menghasilkan lebih tanaman dengan sedikit ruang, sedikit air dan sedikit nutrient. Selain itu, ada aerasi yang baik dan suplai oksigen di sebagian besar sistem hidroponik. Sistem NFT juga sangat mudah dalam pembuatan dan pemeliharaan. Akibatnya, sistem NFT telah menjadi salah satu yang paling populer sistem hidroponik tumbuh dalam dekade terakhir (Farmtech-Mart. 2013). Daya listrik yang dihasilkan oleh surya bergantung pada besar kecilnya intensitas cahaya yang diperoleh oleh modul surya, 
untuk mengantisipasi saat modul surya menghasilkan daya yang kecil maka diperlukan baterai dengan kapasitas yang lebih besar sistem pengecasan aki diatur oleh charge control yang menghindarkan baterai dai kerusakan akibat overcharged (M. Vasugi, 2014).

Berdasarkan analisis terhadap kondisi tersebut, maka dipandang perlu melakukan pengabdian yang berjudul "Pemberdayaan Masyarakat Desa Meuria Paloh Melalui Transfer Teknologi Hidroponik Sayuran Organik Berbantuan Panel Surya (hydroponic solar panels) dalam Membangun Perekonomian Masyarakat Terdampak Pademi Covid-19".

\section{METODE}

Metode Pelaksanaan adalah menggunakan metode survei lapangan dengan cara menentukan permasalahan mitra, berdasarkan hasil analisa situasi pada mitra yang sudah dilakukan melalui survey pendahuluan.

Adapun tahapan pelaksanaanya sebagai berikut:

Tabel 1. Tahapan Pelaksanaan Kegiatan

\begin{tabular}{|c|c|c|}
\hline Tahapan & Kegiatan & Pelaksanaa \\
\hline $\begin{array}{l}\text { Identifikasi } \\
\text { Masalah dan } \\
\text { Observasi } \\
\text { awal }\end{array}$ & $\begin{array}{l}\text { Indentifikasi Masalah } \\
\text { dan Observasi awal } \\
\text { dilakukan oleh peneliti } \\
\text { di lapangan }\end{array}$ & $\begin{array}{l}\text { Team pengabdian mengunjungi } \\
\text { mitra tanaman hidroponik } \\
\text { (kelompok masyarakat) serta } \\
\text { wawancara permasalahan yang } \\
\text { dialami mitra sera observasi awal }\end{array}$ \\
\hline $\begin{array}{l}\text { Peningkatan } \\
\text { Produktivitas }\end{array}$ & $\begin{array}{lr}\text { Peningkatan } & \\
\text { Produktivitas } & \\
\text { dilakukan } & \text { dengan } \\
\text { rancang } & \text { bangun } \\
\text { rangkaian } & \text { alat } \\
\text { hidroponik } & \text { berbasis } \\
\text { panel surya } & \end{array}$ & $\begin{array}{l}\text { a. Perancangan Perangkat } \\
\text { (Formulation, Preliminary } \\
\text { Desain, Desain Detil) } \\
\text { b. Pembuatan (Proses Produksi) } \\
\text { c. Introduksi alat ke mitra dan } \\
\text { evaluasi }\end{array}$ \\
\hline $\begin{array}{l}\text { Penyusunan } \\
\text { SOP }\end{array}$ & $\begin{array}{l}\text { Mendiskusikan SOP } \\
\text { Produksi dan proses } \\
\text { produksi } \\
\text { masing-masing mitra }\end{array}$ & Mengesahkan SOP \\
\hline $\begin{array}{l}\text { Pelaksanaan } \\
\text { pengabdian } \\
\text { dan Kegiatan } \\
\text { Seminar } \\
\text { dengan } \\
\text { Masyarakat }\end{array}$ & $\begin{array}{l}\text { Penyampaian materi } \\
\text { seminar meliputi : } \\
\text { Aspek strategi, Aspek } \\
\text { penghematan energy } \\
\text { dan penggunaan panel } \\
\text { surya, Aspek } \\
\text { penjualan }\end{array}$ & $\begin{array}{l}\text { Mitra dan team pengabdian } \\
\text { melaksanakan seminar di desa }\end{array}$ \\
\hline $\begin{array}{l}\text { Evaluasi } \\
\text { Produk }\end{array}$ & $\begin{array}{lr}\text { Penyebaran angket } \\
\text { kegiatan } \\
\text { masyarakat binaan }\end{array}$ & Pengolahan hasil angket \\
\hline $\begin{array}{l}\text { Penyusunan } \\
\text { Laporan } \\
\text { Akhir } \\
\text { Luaran }\end{array}$ & $\begin{array}{l}\text { Melakukan } \\
\text { pengumpulan data } \\
\text { hasil akhir } \\
\text { Melaksanakan Luaran }\end{array}$ & $\begin{array}{l}\text { Publikasi ilmiah pada jurnal } \\
\text { pengabdian berbasis OJS dan } \\
\text { publikasi media cetak atau online }\end{array}$ \\
\hline
\end{tabular}


Pompa panel surya hidroponik sistem dft dapat menghidupkan pompa selama ada matahari dan malam hari, $100 \%$ bebas pln, kapasitas dapat di desain costumize sesuai kebutuhan.

Aplikasi alat ; system dft hobbis

Spesifikasi : panel 50wp box
Aki 20ah MF
Tombol on off
Kabel Set
Lampu 3 watt
Pompa dc h $5 \mathrm{~m}$
Berat $9 \mathrm{~kg}$

b. Deskripsi kit hidroponik

$\begin{array}{ll}\text { Spesifikasi } & \text { : Kit hidroponik system NFT/DFT } 80 \text { lubang fullset } \\ & 175 \times 85 \times 145 \mathrm{~cm} \\ \text { Berat asli } 155 \mathrm{~kg} \text { (volume) } & \text { 1 set pipa dan rangka baja ringan } \\ & \text { Bak air } \\ & \text { 80 Netpot } \\ & \text { 150 Rockwool } \\ \text { 150 Flanel } & \text { Nutrisi AB Mix untuk } 300 \text { Liter Air }\end{array}$

\subsection{Parameter yang diamati/diukur}

Prosedur kerja yang dilakukan adalah dengan melibatkan sepenuhnya kelompokkelompok mitra mulai dari lahan dan lokasi program pelaksanaan kegiatan dan perawatan tanaman. Namun dalam hal pembuatan alat berupa panel surya hal tersebut dilakukan oleh ketua dan anggota serta melibatkan tim mitra.

Setelah alat berhasil dirancang barulah ketua dan anggota memperkenalkan atau mendiseminasikan alat tersebut kepada masyarakat. Selanjutnya dilakukan kegiatan inti berupa transfer teknologi hidroponik sayuran organik berbantuan panel surya (Hidroponic Solar Panels) dilahan-lahan mitra. Perawatan dan pemantauan dipantau sepenuhnya oleh kelompok mitra didampingi oleh ketua dan anggota kegiatan. Setelah sayur dapat dipanen kelompok mitra didampingi oleh ketua dan anggota kegiatan menghitung besarnya biaya yang dikeluarkan dalam penanaman sayur organik berbantuan panel surya dan selanjutnya dibandingkan dengan besarnya biaya yang kelompok mitra keluarkan selama sebelum penggunaan panel surya.

Setelah perbandingan yang signifikan didapatkan barulah ketua dan anggota kegiatan melakukan diseminasi produk kepada masyarakat luas sekecamatan dengan mengahdirkan kelompok-kelompok mitra sebagai contoh dan acuan terhadap berhasilnya produk teknologi hidroponik berbantuan panel surya (Hidroponic solar panels) dalam membangun perekonomian masyarakat terdampak pandemi Covid-19 di Desa Meuria Paloh Kecamatan Muara Satu Kota Lhokseumawe Provinsi Aceh.

\section{HASIL DAN PEMBAHASAN}

Berdasarkan hasil yang dilakukan tim peneliti dengan masyarakat muda, diperoleh hasil bahwa tanaman sayuran yang ditanam secara hidroponik itu sangat bermanfaat, artinya tanaman sayuran tumbuh dengan sehat tanpa merepotkan orang untuk menyiramnya, system hidroponik yang dikembangkan dalam pengabdian team dosen lakukan adalah dengan memberdayakan energy terbarukan, melalui panel surya. Panel surya memiliki 2 dioda yang 
berfungsi sebagai dioda pembalik artinya dioda ini bisa mengalirkan arus saat panel surya menghasilkan listrik di siang hari dan sebagai penghalang masuknya arus listrik ke panel surya saat panel surya tidak menghasilkan listrik di malam hari (Saban, Y, 2013).

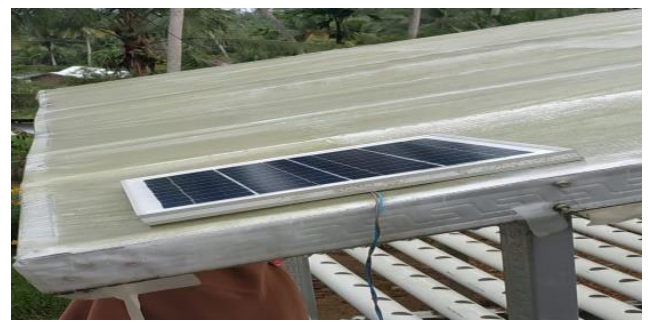

Gambar 6. Pemasangan Panel Surya

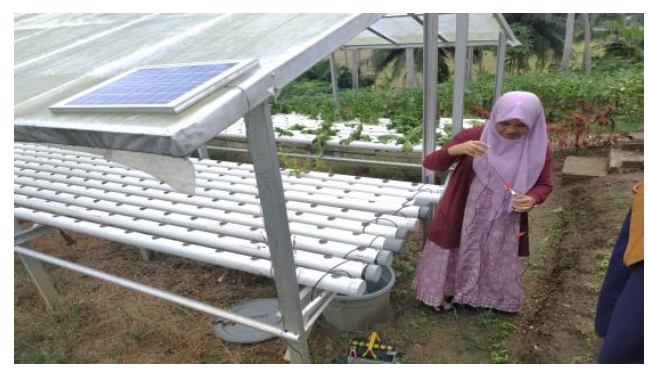

Gambar 7. Tahapan Merakit alat

Prosedur kerja yang dilakukan adalah dengan melibatkan sepenuhnya kelompokkelompok mitra mulai dari lahan dan lokasi program pelaksanaan kegiatan dan perawatan tanaman. Namun dalam hal pembuatan alat berupa panel surya hal tersebut dilakukan oleh ketua dan anggota serta melibatkan tim mitra.

Setelah alat berhasil dirancang, maka ketua dan anggota memperkenalkan atau mendiseminasikan alat tersebut kepada masyarakat. Selanjutnya dilakukan kegiatan inti berupa transfer teknologi hidroponik sayuran organik berbantuan panel surya (Hidroponic Solar Panels) dilahan-lahan mitra. Perawatan dan pemantauan dipantau sepenuhnya oleh kelompok mitra didampingi oleh ketua dan anggota kegiatan. Setelah sayur dapat dipanen kelompok mitra didampingi oleh ketua dan anggota kegiatan menghitung besarnya biaya yang dikeluarkan dalam penanaman sayur organik berbantuan panel surya dan selanjutnya dibandingkan dengan besarnya biaya yang kelompok mitra keluarkan selama sebelum penggunaan panel surya.

Adapun pembahasannya adalah berdasarkan hasil kegiatan yang dilakukan di lokasi Angrowisata Hidroponik dan angket yang disebarkan didapatkan respon dari masyarakat yang luar biasa. Masyarakat dengan antusis menyaksikan penjelasan, pemasangan dan penggunaan panel surya pada rangka hidroponik. Hal ini dikarenakan sebelumnya masyarakat tidak pernah menggunakan panel surya pada rangka hidroponik.

Hal yang lebih menarik lagi yang disampaikan oleh ketua kelompok agrowisata hidroponik Bapak Nazaruddin bahwa dengan penggunaan panel surya pada rangka hidroponik adalah memberikan penurunan pada pemakaian daya listrik. Sehingga dengan tidak langsung sangat menghemat penggunaan aliran listrik dari arus PLN sebagaimna biasanya. 


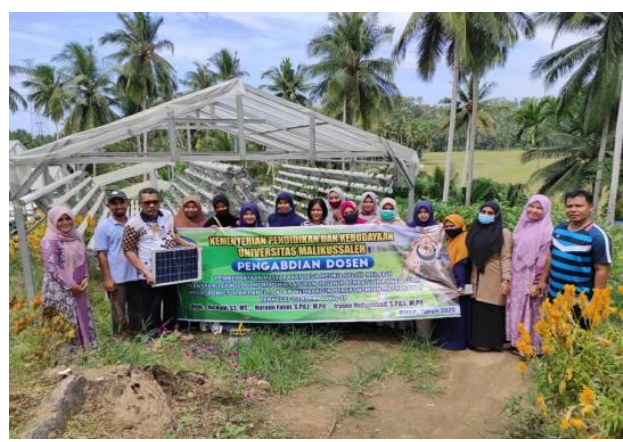

Gambar 8. Seminasi produk ke masyarakat

\section{PENUTUP}

Berdasarkan hasil kegiatan yang dilakukan di lokasi Angrowisata Hidroponik dan angket yang disebarkan didapatkan respon dari masyarakat yang luar biasa. Masyarakat dengan antusis menyaksikan penjelasan, pemasangan dan penggunaan panel surya pada rangka hidroponik. Hal ini dikarenakan sebelumnya masyarakat tidak pernah menggunakan panel surya pada rangka hidroponik. Penghematan biaya yang dikeluarkan secara signifikan memberikan pengaruh terhadap profit yang dihasilkan.

\section{UCAPAN TERIMA KASIH}

Ucapan terima kasih kepada Universitas Malikussaleh yang telah mendanai kegiatan ini melalui dana PNBP Universitas Malikussaleh, kepada agrowisata hidroponik desa meuria paloh yang telah bersedia menjadi mitra dalam kegiatan pengabdian ini serta kepada masyarakat desa meuria paloh yang sudah berpartisipasi aktif dalam kegiatan ini.

\section{DAFTAR PUSTAKA}

Cristian. P. C., Leo. S., Petru. C., Nicoleta. g. (2010). Complex technical solution for renewable energy. Anul XVII, nr.2, 2010, issn 1453-7397. 1-4.

Diah, A.S. (2015). Hidroponik Wick System. Jakarta: Agromedia Pustaka.

Embarsari, et al. (2015). Pertumbuhan Dan Hasil Seledri (Apium graveolens L.) Pada Sistem Hidroponik Sumbu Dengan Jenis Sumbu Dan Media Tanam Berbeda. Bandung ; Jurnal Agro Vol. 2, No. 2.

Farmtech-mart. (2013). Nutrient Film Technique (NFT). Akses pada tanggal 24 Marer 2020. http://www.farmtech-mart.com/hydroponic.

Fathurrahman dkk. Wirausaha Muda Terdidik: Masalah dan Solusi. Jurnal Ilmiah ekonomi dan Bisnis. Vol 15 No 2 (2018). Akses 25 Maret 2020. https://doi.org/10.31849/jieb.v15i2.1464

Hendra, Heru Agus dan Agus Andoko. 2014. Bertanam Sayuran Hidroponik Ala Paktani Hidrofram. Jakarta: Agro media.

Istiqomah, S. (2007). Menanam Hidroponik. Jakarta: Azka press.

M. Vasugi., \& R. Jayaraman. (2014). Sholar charged stand alone inverter. Int. Journal of engineering research and applications, 4, 84-87. Paktani Hidrofram. Jakarta: Agro media.

Roberto, K. (2003). How To Hydroponics 4th Edition. New York : The Futuregarden Press. 
RELATIVITAS: Jurnal Riset Inovasi Pembelajaran Fisika

http://ojs.unimal.ac.id/index.php/relativitas/index
April 2020. Vol.4, No. 1 p-ISSN: 2654-4172 e-ISSN: 2655-8793

Saban,Y., Alev, Y., Mahit, G., Hasan, R., O., (2013). Two-diode model performance analysis of photovoltaic panels. International journal of engineering trends and technology,4,1-6. 